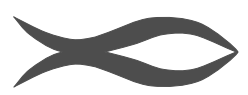

PROOF

\title{
A Comparison of Alternative Circle Hook (Kahle Hook) and J Style Hook Performance in Experimental Pelagic Longline Fishery in Turkey
}

\author{
Aytaç Özgü̈l ${ }^{1 *}$, Ali Ulaş ${ }^{2}$, Altan Lök ${ }^{2}$, F. Ozan Düzbastılar ${ }^{2}$, Cengiz Metin ${ }^{2}$ \\ ${ }^{1}$ Ege University Faculty of Fisheries 35100, Bornova-Izmir, Turkey. \\ ${ }^{2}$ Ege University Research and Application Centre of Underwater 35430, Iskele, Urla-Izmir, Turkey.
}

* Corresponding Author: Tel.: +90 2323115225 ; Fax: +90 2323747450 ;

Received 18 March 2014

E-mail: aytac.ozgul@ege.edu.tr

Accepted 25 February 2015

\begin{abstract}
In recent years, circle hooks have been encouraged as an alternative to traditional J-hooks in pelagic longline fisheries to minimize by-catch mortality and injury to sea turtles and other marine wildlife. Prior to this study, circle hooks had not been used by domestic commercial pelagic longliners in Turkey. The main objective of the study was to evaluate the efficiency of kahle hook comparing with J-style hook baited with sardine (Sardina pilchardus) in pelagic longline fishery in the Aegean coast of Turkey (Kuşadası Bay).We used conventional J-style hooks (Mustad 2315DT-4/0) and kahle hooks (Eagle Claw142A-6/0) for each fishing operation and compared catch rates, catch compositions of target and non-target species. The relative performance of kahle and traditional $\mathrm{J}$-style hooks was tested during 22 valid pelagic longline fishing operations between August 2010 and December 2012. A total of 2200 hooks were used equally amongkahle and J-style hooks consecutively. Captured fish were identified, total and fork lengths were measured,weighed, the time of haulback, and hook type as well as by-catch fish were recorded. A total of 78 fish were caught belonging to 13 species during the samplings. The overall CPUE was 4.73 fishes per 100 hooks for kahle hooks and 2.46 fishes for J-style hooks. For the CPUE of all fishes, the difference was statistically significant $(Z=-1.977 ; \mathrm{P}<0.05)$, in favour of the kahle hook being almost two times greater than the J-style hook. Likewise CPUE was $17007.69 \mathrm{~g}$ per 100 hooks for kahle style hooks and $4807.27 \mathrm{~g}$ for J-style hooks $(\mathrm{Z}=-$ $1.997 ; \mathrm{P}<0.05)$. While no difference was found between two hook models on by-catch species, kahle hooks were more efficient in comparison to J hooks on discard species. Swordfish (Xiphiasgladius) had the highest CPUE (2.82) among all species for kahle hooks followed by silver scabbard fish (Lepidopuscaudatus), 0.64. For J-style hooks, silver scabbard fish catch had the highest CPUE (0.64) followed by swordfish (0.55).
\end{abstract}

Keywords: CPUE, swordfish, kahle hook, pelagic longline fishery, Aegean Sea.

Türkiye'de Pelajik Pareketa Balıkçılığında Kullanılan J Şekilli ve Alternatif C Şekilli (Kahle) İğne Performanslarının Deneysel Olarak Karșılaștırılması

Son yıllarda, pelajik paraketa balıkçılığında deniz kaplumbağaları ve diğer deniz canlılarının ölüm ve yaralanma oranını en aza indirmek için geleneksel olarak kullanılan J şekilli iğnelere alternatif dairesel şekilli iğne kullanımı teşvik edilmektedir. $\mathrm{Bu}$ çalışmadan önce, Türkiye'deki pelajikparaketatakımlarında dairesel şekilli iğneler kullanılmamaktadır. Araştırmanın temel amacı, Türkiye'nin Ege kıyılarında (Kuşadası Körfezi) sardalya (Sardinapilchardus) ile yemlenerek kullanılan pelajik parakete takımlarındaki $\mathrm{J}$ ve dairesel şekilli iğnelerin etkinliğini karşılaştırmaktır.Çalışmada, her paraketa operasyonunda geleneksel J şekilli (Mustad 2315 DT-4/0) iğneler ile bu iğnelere alternatif kullanılan kahle şekilli (EagleClaw 142 A-6/0) iğneler yakalama oranı, hedef ve hedef olmayan türler için av kompozisyonu acısından karşılaştırılmıştır. Ağustos 2010Aralık 2012 tarihleri arasında gerçekleştirilen 22 geçerli pelajikpareketa operasyonunda J ve kahleşekilli iğnelerin performansı test edilmiştir. Paraketalarda ardışık olarak toplam 2200 adet kahleve $\mathrm{J}$ şekilli iğne kullanılmıştır.Yakalanan balıkların total ve çatal boyları ölçülmüş, ağırlıkları alınmış, operasyon zamanı ve iğne tipine göre yakalanan balıklar kaydedilmiştir. Çalışmada 13 türe ait 78 balık yakalanmıştır. Kahleşekilli iğneler için toplam CPUE 4.73 balık/100 iğne, J şekilli iğneler için ise 2,46 balık/100 iğne olarak hesaplanmıştır. Yakalanan tüm balıklar acısından CPUE değerleri arasından istatistiksel açıdan anlamlı bir farklı1ık bulunmuştur $(Z=-1,977 ; \mathrm{P}<0.05)$. Kahle şekilli iğne modeli $\mathrm{J}$ şekilli iğne modeline göre iki kattan daha fazla CPUE değerine sahiptir.Benzer şekilde, kahleşekilli iğneler için CPUE 17007,69 g/100 iğne, J şekilli iğneler için ise 4807,27 $\mathrm{g} / 100$ iğnedir $(\mathrm{Z}=-1,997 ; \mathrm{P}<0.05)$. Hedef dışı türlerin avcıllı̆̆ında her iki iğne modeli arasında bir fark bulunmaz iken discard türlerin avcılığında kahle şekilli iğneler, J şekilli iğnelere oranla daha başarılıdır.Kahle şekilli iğne modelinde en yüksek CPUE 2,82 ile kılıç balığı (Xiphiasgladius) ve 0,64 ile palaska balığına (Lepidopuscaudatus) ait iken J şekilli iğne modelinde en yüksek CPUE 0,64 ile palaska ve 0,55 ile kılıç balığına aittir.

Anahtar Kelimeler: CPUE, Pelajik Paraketa, Dairesel(Kahle) İğne, Kılıç Balığı Avcılı̆̆ı, Ege Denizi

(c) Published by Central Fisheries Research Institute (CFRI) Trabzon, Turkey

in cooperation with Japan International Cooperation Agency (JICA), Japan 


\section{Introduction}

Pelagic longline is a passive fishing gear where are set throughout the water column or near the surface of the water is composed of baited hooks are attached at intervals to main line by short lines called branch line or snood (Suzuki et al., 1977). Pelagic longlines are usually used to catch swordfish and tuna species worldwide (Kerstetter et al., 2007; Beverly et al., 2009), however, they catch another species or juveniles of the target species called non-target species or by-catch(Dunn et al., 2008). Non-target species can be classified into two groups as incidental and discarded. Incidental species are not targeted but are retained for commercial purposes. Discarded species are thrown away because they are noncommercial, undersized and protected species (Beverly et al., 2009). In the study, longline catch is classified in two groups as target and non-target catch. Non-target catch is composed of incidental (commercial sp.) and discarded (non-commercial sp.) species.

Pelagic longline fishery is prone to the incidental catch resulting in mortality of captured fish (Coryphaeanahippurus, Serioladumerili, etc.) and other species such as sharks, rays, sea turtles and seabirds etc. (Lewison et al., 2004;Kerstetter and Graves, 2006). Pelagic longlines have been used to catch mainly swordfish, bluefin tuna (Thunnusthynnus) and albacore (Thunnusalalunga) in the Mediterranean Sea for many years (Lewison et al., 2004;Gabr and El-Haweet 2012). Swordfish has been the target species of pelagic longline fishing for over fifty years inTurkey as well. Conversely, swordfish pelagic longliners also catch other species such as Thunnus sp., dophinfish (C. hippurus), Mediterranean spearfish (Tetrapturusbelone), bullet tuna (Auxisrochei), sharks, sea turtles and seabirds (Akyolet al., 2005; Akyol and Ceyhan, 2011). For swordfish capture in the Mediterranean Sea, the Standing Committee for Research and Statistics (SCRS) of the International Commission for the Conservation of Atlantic Tunas (ICCAT) indicated that technical modifications of pelagic longline gears needed to reduce the catch of juveniles (ICCAT, 2011; Graves et al., 2012; Akyol and Ceyhan, 2013). In 2010, it was reported that 50 longline vessels employed 14 different pelagic longlines, extending up to $30 \mathrm{~km}$ mainline ranging from 8-500 J-style hooks in each gear between the depths of 60-3000 $\mathrm{m}$ in Turkish Seas (Ceyhan and Akyol, 2009; Akyoland Ceyhan, 2010;2011).

Some fishing gear and hook modifications such as shape and size of hooks, bait types and different fishing depths were performed to reduce incidental species and discard mortality in pelagic longline fishery (Hall et al., 2000; FAO, 2009). The wellknown application was the substitution of J-style hooks with circle hooks (Prince et al., 2002; Horodysky and Graves 2005; Gilman et al.,
2007) to reduce discard and by-catch mortality preventing serious injury associated with the use of traditional J-style hooks and increase catch rates of target species (Kerstetter and Graves, 2006; Pacheco et al., 2011). The catch rates of the captured species in the longline fisheries are influenced by many factors as technique of fishermen (Dunn et al., 2008), various biological and environmental dynamics (Bach et al., 2009), bait type, soak time and operation depths (Bjordal,1989; Song et al., 2012). The objectives of this study were to compare the performance of traditional J-style and kahle hooks in pelagic longlines on catch composition, catch rates and catch per unit effort (CPUEs), in the Aegean Sea, Turkey.

\section{Materials and Methods}

Hook comparisontrials were conducted from August 2010 to December 2012 in the Bay of Kuşadası covering depths between 70 and $150 \mathrm{~m}$ (Figure 1).22 fishing operations were performed by a boat ( $8.5 \mathrm{~m}$ length, $20 \mathrm{HP}$ ) between latitudes $38^{\circ} 00^{\prime} \mathrm{N}$ to $38^{\circ} 02^{\prime} \mathrm{N}$ and longitudes $26^{\circ} 55^{\prime} \mathrm{E}$ to $27^{\circ} 05^{\prime} \mathrm{E}$. The fishing gear consisted of 50 kahle (Eagle Claw 142A-6/0) and 50 J-style (Mustad 2315DT-4/0)hooks, which were structurally similar to commercial pelagic longlines. Mainline of the experimental longline was made of polyamide (PA) multifilament $(210 \mathrm{~d} / 54)$ treated with paint, wax and kerosene. Furthermore, 100 branch lines were constructed to mainline which were made of monofilament material, with diameter of $0.8 \mathrm{~mm}$ and length of $5 \mathrm{~m}$. Snoods were connected to $1500 \mathrm{~m}$ main line with swivels and hooks were equipped to longline consecutively (J-K-J-K-J).Buoys were used in $70 \mathrm{~m}$ intervals for positioning the mainline to ensure the required operation depths. Both ends of the mainline were anchored to fix the fishing gear (Figure 2).

The baited hooks with sardine (S.pilchardus) were set manually at sunset and hauled back early in the next morning. Before each trial number of two different hooks were checked to guarantee if they were equal. Moreover, all structural conditions of the longline were constant in each trial to make an accurate comparison between the catch rates of kahle and J-style hooks. Although longliners are not allowed to use hooks smaller than size $2 / 0$, it was observed that fishermen use an illegal hook size $4 / 0$ for swordfish capture in the study area. Patterns and measurements of both legal (J-style, size 2/0) and illegal (J-style, size 4/0 and kahle, 6/0) hooks were illustrated in Figure 3. The gap size of kahle hook (curved shank) was $26.8 \mathrm{~mm}$ whereas the maximum width of the hook was $29.1 \mathrm{~mm}$. The distance between point and shank of J-style hook size 4/0 was $22.6 \mathrm{~mm}$ and its widest point was $25.7 \mathrm{~mm}$. Legal Jstyle hook size $2 / 0$ had $27.3 \mathrm{~mm}$ gap and the distance at the widest point of bend was $30.6 \mathrm{~mm}$. In the study, coated nickel material kahle hook had a ringed hook 


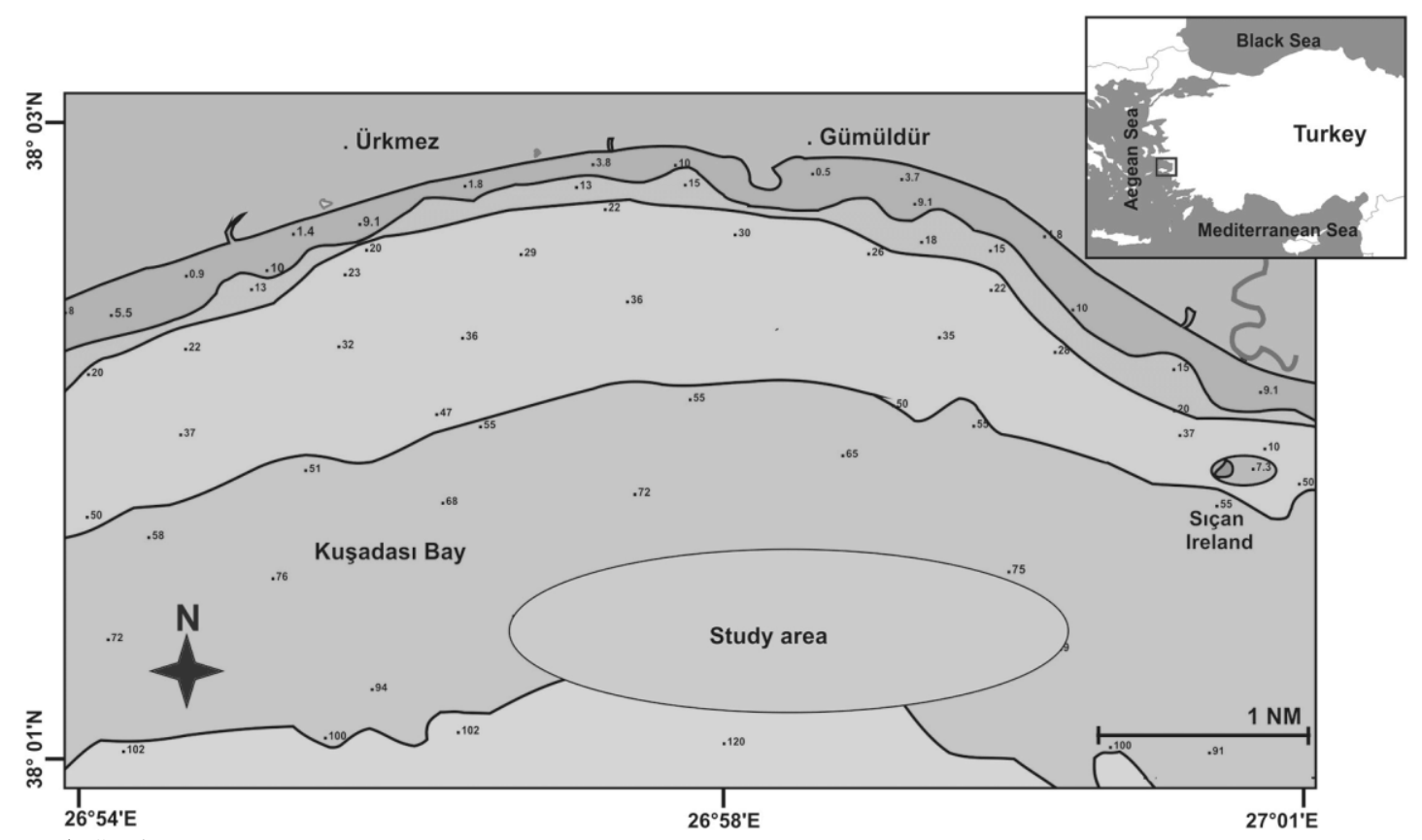

Figure 1. Study area

a)

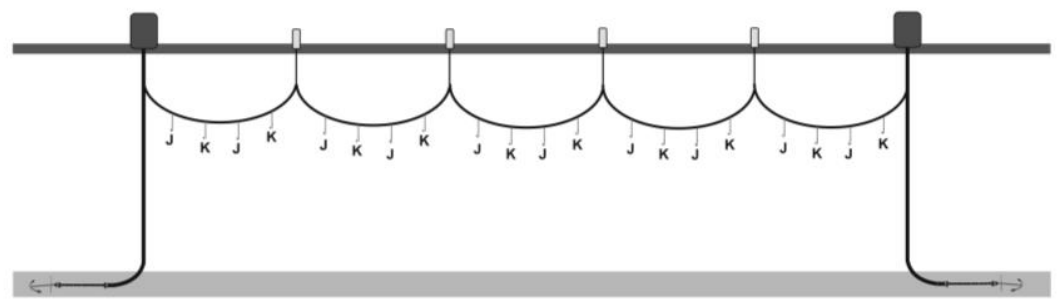

b)

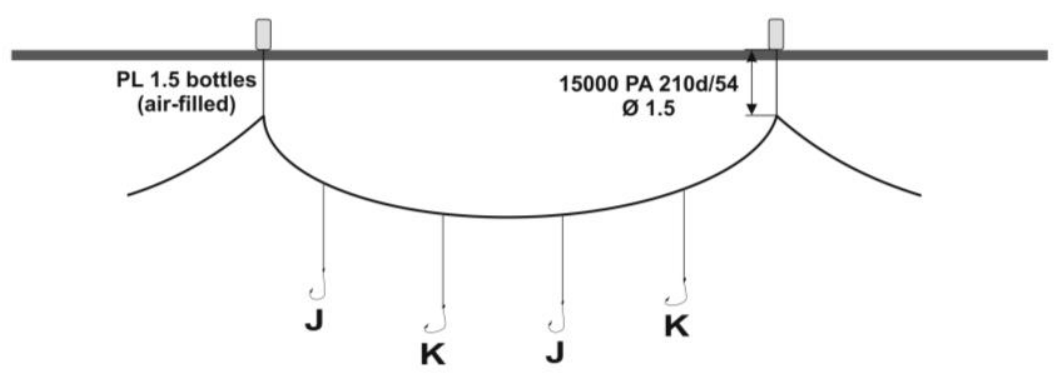

c)

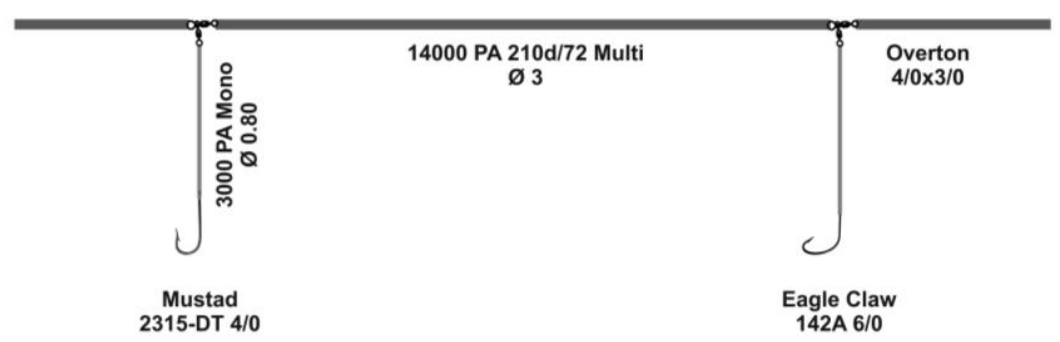

Figure 2. Schematic drawings of buoys, branch lines and anchors belonging to pelagic longline used in trials. 


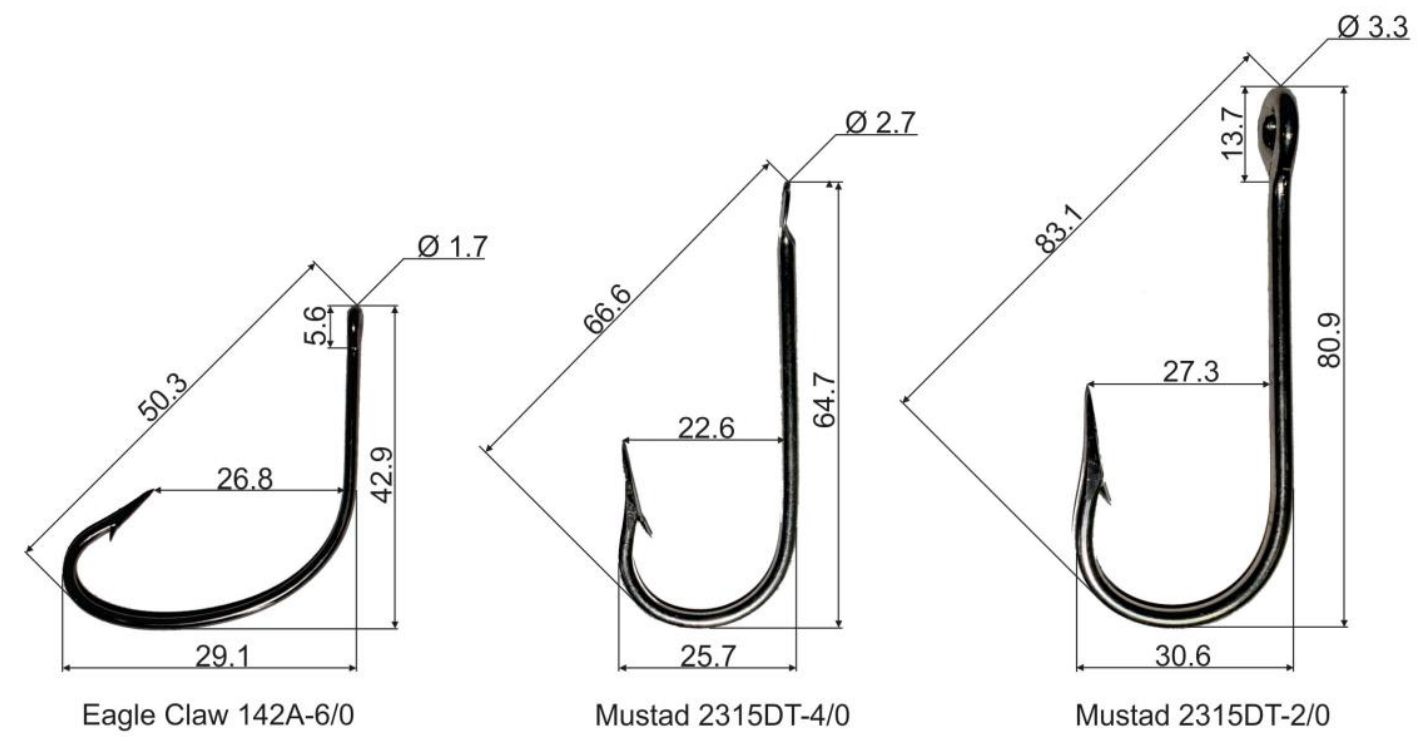

Figure 3. Images of two hook types (kahle hook-size 6/0 and "J-style" hook-size 4/0) used in the study and the legal "Jstyle" hook-size $2 / 0$.

eye whereas zinc-steel J-style hook had a flattened hook eye.

During the survey, soak time, bait loss, hook loss and number of fish caught were recorded by considering the hook types. The fishes were identified, weighed and their total and fork lengthswere measured.Number of fish occupying different hooks (J-style and kahle), was stated as a percentage of the total number of hooks. Catch rates and CPUEs of hook and fishing gear wascalculated considering fish numberand total weight for 100 hooks (De Metrio and Megalofonou, 1988). The fishing effort $(f)$ and CPUEs can be found by using equation (1), (2), and (3). In equation (1), where $f$ is the fishing effort, $a$ ' the average number of hooks in longline per day, and $d$ the number of fishing days per trip. CPUE can be expressed as a function of the fishing effort $(f)$ in equation (2) and (3), where CPUE is catch per unit effort, $N$ the number of fish caught, and $B$ the weight of fish caught.

$$
\begin{aligned}
& f=\left(a^{\prime} / 100\right) \cdot d \\
& \text { CPUE }=N / f \\
& \text { CPUE }=B / f
\end{aligned}
$$

Equation (1)

Equation (2)

Equation (3)

Differences in CPUE between kahle and J-style hooks for the species $>10$ individuals were tested with paired $t$-tests after performing the $\mathrm{X}^{\prime}=\log (\mathrm{X}+1)$ transformation to conform to the assumption of normality (Zar, 1996). While length of swordfish was measured by using lower jaw-fork length (LFJL) sharks and other fish were measured in total length. Nevertheless, length frequency diagram of swordfish as being target species of this study was drawn in 5 $\mathrm{cm}$ intervals. The Wilcoxon Signed Rank test was used to assess whether kahle and J-style hooks had the same capture rate, expressed as CPUE (number of fish and weight per 100 hooks). CPUEs of kahle and J- style hooks were compared pair wise (pairs of $\mathbf{J}$ and kahle hooks within experimental sets). Statistical significance was declared at $\mathrm{p}<0.05$ level.

\section{Results}

Pelagic longline experiments carried out from August 2010 to December 2012, whereas 28 fishing operations were performed however six trials were cancelled due to gear loss (weather condition, trawlers etc.). The soak time was fixed as $14 \pm 1$ hour in all fishing trips. In the experiments, a total of 78 fishes belonging to 13 species were caught (Table 1). In total, 12 non-target fish species were captured by the pelagic longline. Incidental catchwas consisting of 8 fish species with market value, while4sharks and rays specieswere discarded because they either have no commercial value during longline trials.Swordfish dominated the catch composition followed by silver scabbardfish (L.caudatus) and dolphinfish ( $C$. hippurus), European hake (Merlucciusmerluccius), chubmackerel (Scomberjaponicus), bogue (Boopsboops), spotted catshark (Scyliorhinuscanicula), common smooth-hound (Mustelusmustelus) and other fishes captured with only one specimen. Approximately, half of captured fish in terms of number $(47.4 \%)$ was composed of swordfish corresponding to $71.2 \%$ of total weightof thecatch composition (Table 1). A total of 37 swordfish were caught over 22 fishing trips, which were completely smaller than minimum landing size $(>125 \mathrm{~cm})$ (Anonymous, 2012).

It was found that $66 \%$ of fish were captured with kahlehooks, which also mean $77 \%$ of the total catch (weight). Moreover, $84 \%$ percent of swordfish specimen composing $88.5 \%$ of the total catch weight was obtained by kahle hooks. Regarding the non- 
target species, it was determined that $57.1 \%$ (number of fish) of the incidental catch corresponding to $63.1 \%$ of the total catch weight was caught with kahle hooks. In addition to this discarding rate of kahle hooks was found as $16.7 \%$ and $2.1 \%$ in terms of number and weight respectively.

The overall CPUE was 4.73 for kahle hooks and
2.46 for J-style hooks as given Table 2 and Figure 4. For the CPUE of all fishes, the difference was statistically significant $(Z=-1.977 ; P<0.05)$, with the value for the kahle hook being more than about two times greater than with the J-style hook. Likewise CPUE was $17007.69 \mathrm{~g}$ for kahle style hooks and $4807.27 \mathrm{~g}$ for J-style hooks. CPUE for kahle hook

Table 1. Catch composition by fish group, species and hook type

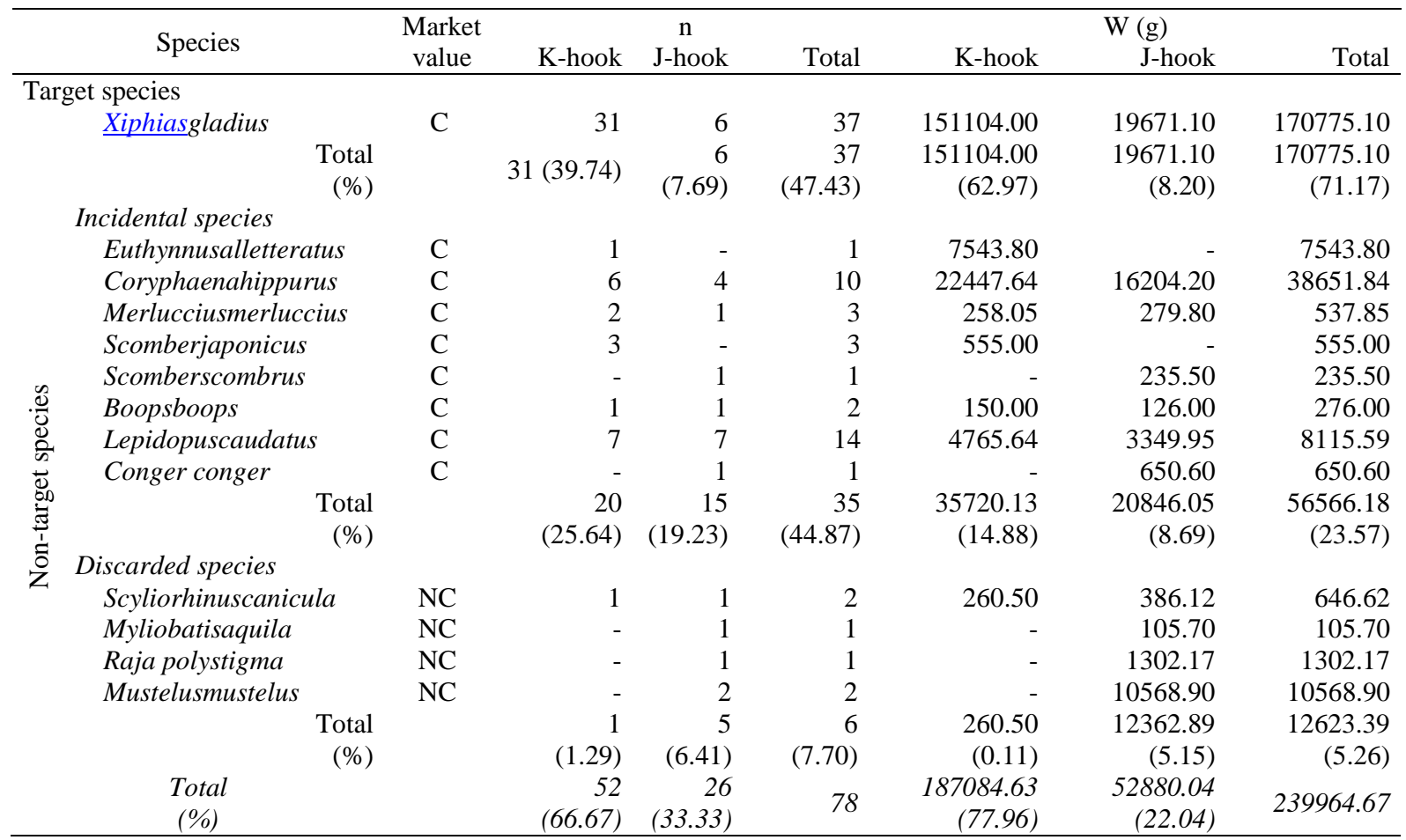

*(C: Commercial, NC: Non-commercial, n: Fish number, W: Fish weight $)$

Table 2.Catch in number and catch rate (CPUE-fish /100 hook and CPUE-g/100 hook) by species and hook type

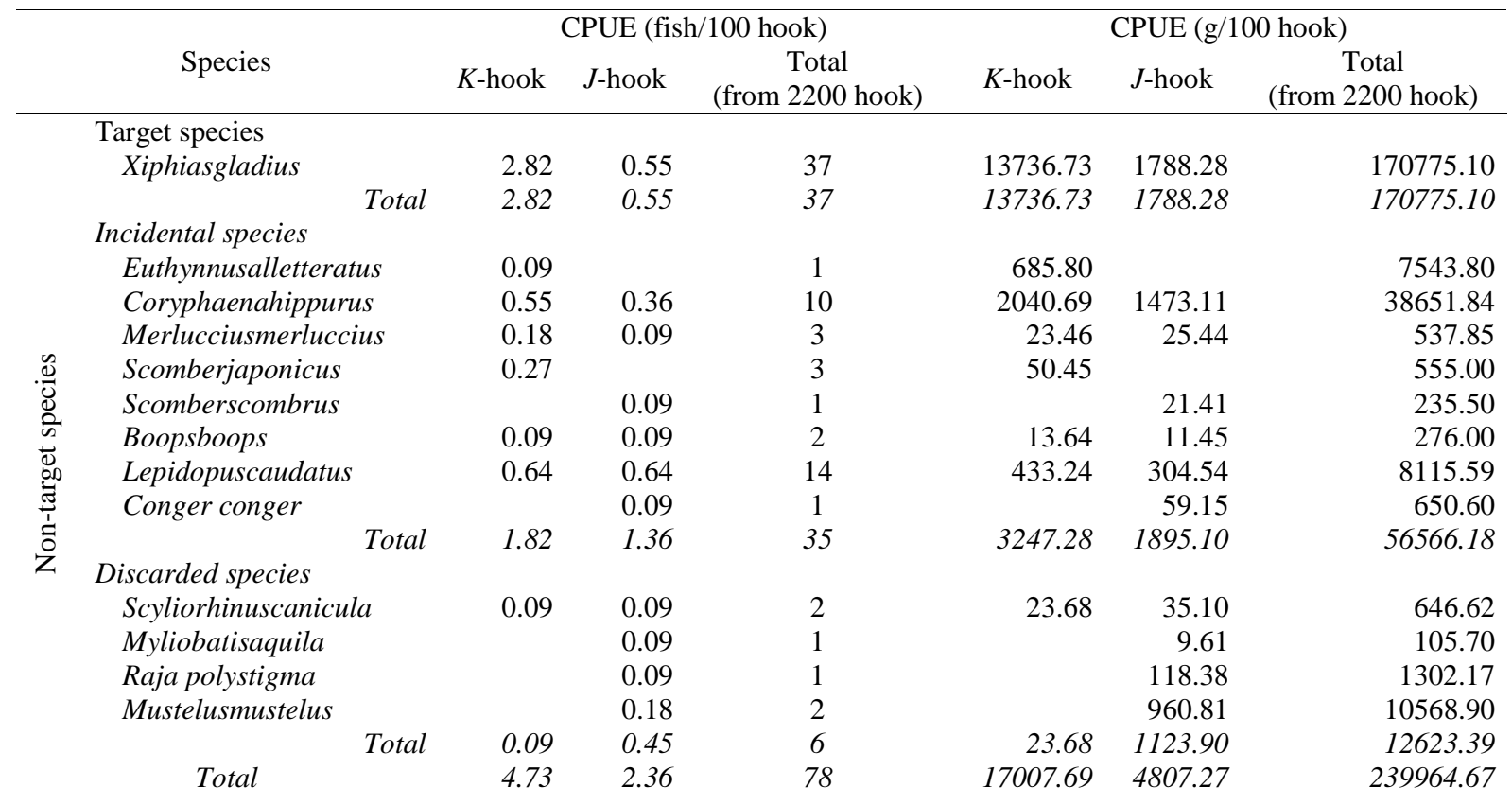


was higher than the value of J-style hook $(Z=-1.997$; $\mathrm{P}<0.05)$. Swordfish captured with kahlehooks had the highest CPUE with a value of 2.82 followed by silver scabbardfish with 0.64 , dolphinfish and chub mackerel with 0.55 and 0.27 respectively. Considering the J-style hooks it was found that, silver scabbardfish catch had the highest CPUE (0.64) followed by swordfish (0.55) and dolphinfish (0.36).

Nevermore, statistically significant difference was determined for CPUE of swordfish regarding the hook types $(Z=-2.788$; $\mathrm{p}<0.05)$, as kahlehooks had five times greater value than J-style hooks. A similar situation was also determined for weights as CPUE of kahle hooks was higher than CPUE of J-style hooks (CPUE kahle 13736.73 g, CPUE J-style $1788.28 \mathrm{~g}$ ). There was a significant difference between two different types of hook on CPUE values $(\mathrm{Z}=-2.605 ; \mathrm{P}<0.05)$. Among the discard species consisting of sharks and rays, kahlehooks had lower catch than J-style hooks. The difference in CPUE of incidental catch and discard species was statically insignificant $(\mathrm{P}>0.05)$.

Swordfish captured by kahlehooks ranged in length from 54.4 to $106.8 \mathrm{~cm}$, while hooked individuals by J-style ranged from 56.5 to $82.4 \mathrm{~cm}$. The most common length class for swordfish was 70 $\mathrm{cm}$ with 16 individuals (Figure 5).

It was observed that, 13 kahle and $11 \mathrm{~J}$ hooks were detached by fish. The potential causes of detached hooks are thought to be $C$. hippurus and $M$. mustelus. Kahle hooks are considered to be taken easily, and detached by fish due to their shape but no difference was determined on detachment ratio between two hook models.

\section{Discussion}

Recent studies relating to use of circle hooks have been performed to reduce incidental catch and discarded species in pelagic longline fishery (Watson et al., 2005; Promjinda et al., 2008; Piovano et al., 2010; Domingo et al., 2012; Graves et al., 2012).Circle hooks have been promotedas an alternative to traditional $\mathrm{J}$-style hooks in pelagic longline fishery to obtaindiscardreduction (Kerstetter and Graves, 2006; Pacheco et al., 2011) and also increase catch rates (Falterman and Graves 2002;Kerstetter et al., 2007). Circle hooks reduce sea turtle catch, sharks, and rays and occasionally increase target catch (Megalofonou et al. 2005; Watson et al., 2005; Yokata et al., 2006). In addition, circle hooks can reduce the possibility of deep hooking (Cooke and Suski, 2004), mouth or jaw injuries influencing by hook shape (Kerstetter and Graves, 2006; Prince et al., 2007), and reduce mortality for catch and release fisheries (Prince et al., 2002; Kerstetter and Graves, 2006; Graves and Horodysky, 2008).In our study, one small-spotted catshark (S. canicula) was hooked by circle hooks, while three sharks captured by J-style hooks.

Kim et al. (2006) sampled 25 fish species (735 fish) and three individuals of sea turtle during the fishing operations. Kerstetter and Graves (2006) caught a total of 22 and 29 species in the fall and spring fishery, respectively. In our experiments, a total of 78 fishes belonging to 13 fish species were caught. Whereas $X$. gladius was the targeted species and 12 non-target fish species were captured by the pelagic longline ( 8 incidental species and 4 discarded species). Total catch was dominated by $X$. gladius (47.4\%) followed by L. caudatus and C. hippurus.

In swordfish and tunalonglining, catch composition are influenced by many factors such as hook type, deployment depth, soak time, bait type etc. (Broadhurst and Hazin, 2001; Bigelow et al., 2006; Dunn et al., 2008; Bach et al., 2009; Song et al., 2012). It is considered that the use of circle hooks is resulted in greater catch rates than J-style hooks (Falterman and Graves 2002;Kerstetter and Graves,

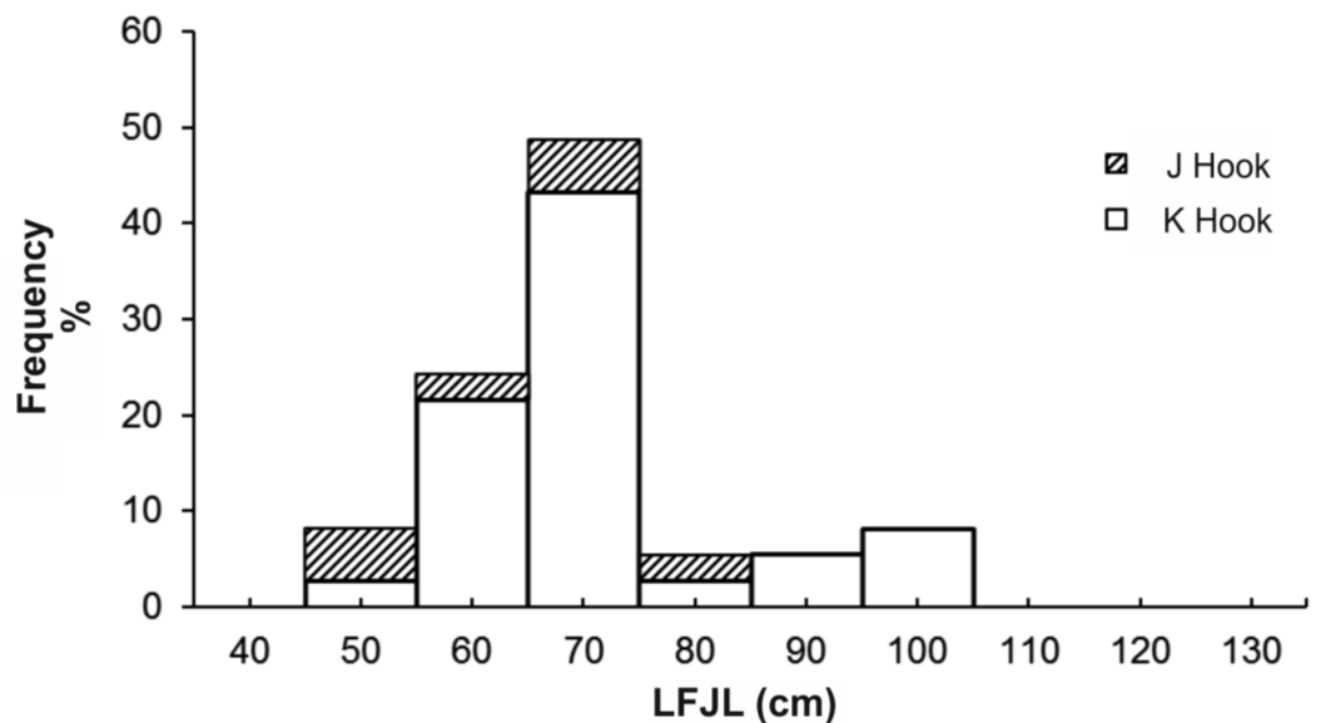

Figure 5. Length-frequency diagram for swordfish hooked by kahle and J-styles. 
2006; Kerstetter et al., 2007; Pacheco et al., 2011; Graves et al., 2012). In the study, the overall CPUE was 4.73 for kahlehooks and 2.36 for J-style hooks. For all fishes, CPUE for the kahlehook was about two times greater than the J-style hook. CPUE of kahlehooks in terms of weight was approximate 3.5 times higher than J-style hooks.

Kerstetter et al. (2007) and Promjinda et al (2008) calculated that circle hooks $(11.6 ; 1.91)$ had higher CPUE than J-style hooks $(8.6 ; 1.43)$ for swordfish. In contrast, Piovana et al. (2009) reported that swordfish CPUEs were 13.0 on circle hooks and 14.5 on J-style hooks. We found significant difference in catch rates of target species between alternative circle and J-style hooks. In our study the CPUE of kahlehook was calculated about 5 times greater than J-style hook.

Promjinda et al (2008) reported that non-target species' CPUE (individuals/1000 hook) were 5.58 on J-style hooks and 2.55 on circle hook. CPUEs of shark and rays were 3.34 and 1.43 for $\mathrm{J}$ and circle hooks, respectively. In our experiments, CPUEs of J and kahlehooks for sharks and rays were found 0.45 and 0.09 , respectively. In our study, among the discard species consisting of sharks and rays, kahlehooks had lower catch than J-style hooks however incidental catch and discard species' CPUEs were quite similar.

In Kuşadası Bay where the study performed, swordfish fishing by pelagic longlines has been started since 2003 (Akyol and Ceyhan 2011; 2013). It was reported that swordfish ranging in length from 51 to $242 \mathrm{~cm}$ were caught by longline and gillnets in the site, furthermore swordfish individuals smaller than minimum landing size $(125 \mathrm{~cm})$ were particularly captured by longlines. Similarly, all captured individuals composed of undersized fish in the experiments. Nevertheless, pelagic longlining should be promoted considering the issue of selectivity and discard mortality during the drift net restricted period.

Many studies conducted in Aegean Sea and Mediterranean resulted with fish below minimum landing size (MLS $=125 \mathrm{~cm}$ in Turkish Fisheries Regulation Notification no. 2/1, SÜR-KOOP, 2008). and in the eastern Mediterranean and also Aegean Sea, catch-at-sizes of swordfish were ranged from 98.0 to $295.0 \mathrm{~cm}$ (Artüz, 1963), 87.6 to $206.7 \mathrm{~cm}$ (Tsimenides and Tserpes, 1989), 62.0 to $205.0 \mathrm{~cm}$ (Tserpes and Tsimenides, 1995), 51.0 to $74.0 \mathrm{~cm}$ (Megalofonou et al., 1995),25.0 to $135.0 \mathrm{~cm}$ (De Metrio et al., 1997), 52.5 to $219.0 \mathrm{~cm}$ (Alıçlı and Oray, 2001), 67.5 to176.0 cm (Alıçlı, 2008), 60.0 to $240.0 \mathrm{~cm}$ (Ceyhan and Akyol, 2009), 60.0 to 172.0 $\mathrm{cm}$ (Akyol and Ceyhan, 2011), 87.0 to $188.5 \mathrm{~cm}$ (Alıçlı et al., 2012) and 51.0 and $242.0 \mathrm{~cm}$ (Akyol and Ceyhan, 2013). In this study all samples were below MLS (54.4-106.8 cm). Smaller fish are attributed to be depth of the study area $(70-150 \mathrm{~m})$.
Furthermore, kahle hooks caught bigger fish than $\mathrm{J}$ hooks. It was reported that the average swordfish length captured by longlines was $85.9 \pm 1.3 \mathrm{~cm}$ in Turkey (Akyol and Ceyhan, 2011). A mean length of $76.1 \pm 2.2 \mathrm{~cm}$ was determined for Kahle hooks. Behavior of swordfish to the bait is to attack and slice (Tibbo et al., 1961). It is thought that kahle hooks are more effective in catching the fish due to their structural characters while the fish is tricking with the bait. Further studies in deeper waters with bigger hook sizes are considered to contribute the scientific literature on catch efficiency and selectivity of these hooks.

Our results showed that the use of alternative circle (kahle) hooks reduces the capture of a few bycatch species while increasing the catch of some target species. However, other factors such as size and shape of hooks, gear configuration, type and size bait, and time of setting, among others, should also be considered in future studies.

\section{Acknowledgements}

This study was funded by Ege University Underwater Research and Application Center (SAUM Project no: 2011/SAUM/003). The authors are also grateful to B. Rüzgar and Ö. Ergün for their logisticalsupports. We also thank C.Pelister, B. Maktay, H. Kaykaç, B. Güland O.Soykanfor their help during the trips.

\section{References}

Alıçlı, T.Z. 2008. Biometric relationships and condition factor of swordfish, Xiphiasgladius L., 1758. İ.Ü. Su Ürünleri Dergisi, 23: 29-39.

Alıçlı, T.Z. and Oray, I.K. 2001, Age and growth of swordfish (Xiphiasgladius L., 1758) in the eastern Mediterranean Sea.ICCAT, Collective Volume of Scientific Papers. 52(2): 698-707.

Alıçlı, Z., Oray, I.K., Karakulak, S.F. and Kahraman, A.E. 2012. Age, sex ratio, length-weight relationships and reproductive biology of Mediterranean swordfish, Xiphiasgladius L., 1758, in the Eastern Mediterranean.African Journal Biotechnolgy, 11: 3673-3680.doi: 10.5897/AJB11.2189

Akyol, O., Erdem,M.,Ünal, V. andCeyhan, T. 2005.Investigations on Drift-Net Fishery for Swordfish (Xiphiasgladius L.) in the Aegean Sea. Turkish Journal of Veterinary \&Animal Sciences, 29 (6): $1225-1231$

Akyol, O.and Ceyhan, T. 2010.Pelagic longlines for swordfish used in Turkish seas. Ege Journal of Fisheries and Aquatic Sciences,27(4): 149-156 (in Turkish).

Akyol, O. and Ceyhan, T. 2011.The Turkish Swordfish Fishery.ICCAT,Collective Volume of Scientific Papers,66(4):1471-1479.

Akyol, O. and Ceyhan, T. 2013.Age and growth of swordfish (Xiphiasgladius L.) in the Aegean Sea.The 
Turkish Journal of Zoology, 37: 5964.doi:10.3906/zoo-1204-3

Anonymous, 2012.Turkish Fishery Regulation Bulletin (3/1) for Marine and Inland Commercial Fisheries in Fishing Season 2012-2016.Rep. of Turkey Ministry of Food, Agriculture and Livestock, Gen.Direc.of Fisheries and Aquaculture, (2012/68), Ankara, 112p. (in Turkish).

Artüz, M.I. 1963. Contribution to the knowledge of the biology of the swordfish (Xiphiasgladius L.) in the Sea of Marmara. Proc. Gen. Coun. Medit. 7: 459-471.

Bach, P., Gaertner, D., Menkes, C., Romanov, E. and Travassos, P. 2009. Effects of the gear deployment strategy and current shear on pelagic longline shoaling. Fisheries Research, 95: 5564.doi:10.1016/j.fishres.2008.07.009

Beverly, S., Curran, D., Musyl, M. and Molony, B. 2009.Effects of eliminating shallow hooks from tuna longline sets on target and non-target species in the Hawaii-based pelagic tuna fishery.Fisheries Research, 96: 281-288.doi:10.1016/j.fishres.2008.12.010

Bigelow, K.,Musyl, M.K., Poisson, F. and Kleiber, P. 2006. Pelagic longline gear depth and shoaling.Fisheries Research, 77 :

$173-$ 183.doi:10.1016/j.fishres.2005.10.010

Bjordal, A. 1989.Recent developments in long-line fishingcatching performance and conservation aspects.In: Proccedings of the World Symposium on Fishing Gear and Fishing Vessel Design, November 1988, Mar. Inst., St John's, Newfoundland, Canada, pp.1924.

Broadhurst, M.K. and Hazin, F.H.V. 2001.Influences of type and orientation of bait on catches of swordfish (Xiphiasgladius) and other species in an artisanal subsurface longline fishery off Northeastern Brazil. Fisheries Research, 53, 169-179.doi:10.1016/S01657836(00)00297-6

Ceyhan, T. and Akyol, O. 2009. The swordfish (Xiphiasgladius) fishery in the Turkish Aegean Sea.ICCAT, Collective Volume of Scientific Papers,64(6): 2069-2078.

Cooke, S.J. and Suski,C.D. 2004. Are circle hooks an effective tool for conserving marine and freshwater recreational catch-and-release fisheries? Aquatic Conservation: Marine and Freshwater Ecosystems, 14:299-326. doi:10.1002/aqc.614

De Metrio, G. and Megalofonou, P. 1988. Catch, size distribution, growth and sex ratio of swordfish (Xiphiasgladius L.) in the Gulf of Taranto. FAO Fisheries Report No: 394.

De Metrio, G., Cacucci, M., Sion, L., Potoschi, A., Cannavó, G., Romeo, T., Megalofonou, P., Yannopoulos, C. and Kapiris, C., 1997.Catches of juvenile bluefin tuna and swordfish during the albacore long-line fishery in the Mediterranean. Final Report. 1-45. Contract CEE No 94/079.

Domingo, A., Pons, M., Jiménez, S.,Miller, P., Barceló, C. and Swimmer, Y. 2012.Circle hook performance in the Uruguayan pelagic longline fishery.Bulletin of Marine

511.doi:10.5343/bms.2011.1069

Dunn, D.C., Kot, C.Y. and Halpin, P.N. 2008.A comparison of methods to spatially represent pelagic longline fishing effort in catch and bycatch studies. Fisheries Research: 92: 268276.doi:10.1016/j.fishres.2008.01.006
Falterman, B. andGraves, J.E. 2002.A preliminary comparison of the relative mortality and hooking efficiency of circle and straight shank ("J") hooks used in the pelagic longline industry. In: Lucy JA, Studholme AL, editors. Catch and release in marine recreational fisheries. Bethesda, MD: AFS Press. pp. 80-87.

FAO. 2009: Guidelines to reduce sea turtle mortality in fishing operations. FAO, Rome, $128 \mathrm{pp}$.

Gabr, M.H. and El-Haweet, A.E., 2012.Pelagic longline fishery for Albacore (Thunnusalalunga) in the Mediterranean Sea off Egypt.TurkishJournal of FisheriesandAquaticSciences, 12: 735-741. doi: 10.4194/1303-2712-v12_4_01

Gilman, E., Kobayashi, D., Swenarton, T., Brothers, N., Dalzell, P. andKinan-Kelly, I. 2007. Reducing sea turtle interactions in the Hawaii-based longline swordfish fishery. Biological Conservation,139:1928.doi:10.1016/j.biocon.2007.06.002

Graves, J.E. and Horodysky, A.Z. 2008. Does hook choice matter? The effects of three circle hook models on post-release survival of white marlin.North American Journal of Fisheries Management,28:471480.doi:10.1577/M07-107.1

Graves, J.E.,Horodysky, A.Z. and Kerstetter, D.W. 2012. Incorporating circle hooks into Atlantic pelagic fisheries: case studies from the commercial tuna/swordfish longline and recreational billfish fisheries. Bulletin ofMarine Science,88(3):411422.doi:10.5343/bms.2011.1067.

Hall, M.,Alverson, D.L. and Metuzals, K.I. 2000. By-catch: problems and solutions. Marine Pollution Bulletin,41:204-219.doi:10.1016/S0025326X(00)00111-9

Horodysky, A.Z. and Graves, J.E. 2005. Application of popup satellite archival tag technology to estimate post release survival of white marlin (Tetrapturusalbidus) caught on circle and straight-shank ("J") hooks in the western North Atlantic recreational fishery. Fishery Bulletin, 103:84-96.

ICCAT. 2011: Report of the 2010 ICCAT, Mediterranean Swordfish Assessment Meeting (June 28 to July 2, 2010). Madrid, Spain. ICCAT,Collective Volume of Scientific Papers, 66(4):1405-1470

Kerstetter, D.W. and Graves, J.E. 2006.Effects of circle versus J-style hooks on target and non-target species in a pelagic longline fishery. Fisheries Research, 80: 239-250.doi:10.1016/j.fishres.2006.03.032

Kerstetter, D.W., Pacheco, J.C., Hazin, F.H., Travassos, P.E. andGraves, J.E. 2007. Preliminary results of circle and J-style hook comparisons in the Brazilian pelagic longline fishery. ICCAT, Collective Volume of Scientific Papers,60(6):2140-2147.

Kim, S-S., Moon, D-Y., An, D-H. andKoh, J-R. 2006 Comparison of circle hooks and $\mathrm{J}$ hooks in the catch rate of target and bycatch species taken in the Korean tuna longline fishery WCPFCSC2-2006/EB WP-12. Second Regular Session of the WCPFC Scientific Committee, 7-18 August, 2006, Manila, Philippines.

Lewison, R.L., Freeman, S.A. and Crowder, L.B. 2004.Quantifying the effects of fisheries on threatened species: the impact of pelagic longlines on loggerhead and leatherback sea turtles. Ecology Letters,7(3): 221-231.doi: 10.1111/j.1461-0248.2004.00573.x

Megalofonou, P., Dean, J. M., De Mitrio, G., Wilson, C. and Berkelev, S. 1995. Age and growth of 
juvenileswordfish, Xiphiasgladius L., from the Mediterranean Sea. Journal of Experimental Marine Biology and Ecology, 188: 79-88.

Megalofonou, P., Damalas D. and Yannopoulos, C. 2005. Composition and abundance of pelagic sharks bycatch in the Eastern Mediterranean Sea. Cybium, 29(2): $135-140$

Pacheco, J.C., Kerstetterb, D.W., Hazinc, F.H.,Hazina, H., Segundoc, R.S.S.L., Gravesd, J.E., Carvalhoe, F. andTravassosb, P.E. 2011. A comparison of circle hook and $\mathrm{J}$ hook performance in a western equatorial Atlantic Ocean pelagic longline fishery. FisheriesResearch,107: 45.doi:10.1016/j.fishres.2010.10.003

Piovano, S., Clò, S. and Giacoma, C. 2010. Reducing longline by-catch: The larger the hook, the fewer the stingrays. Biological Conservation, 143: 261264.doi:10.1016/j.biocon.2009.10.001

Prince, E.D., Ortiz, M., Venizelo, A., 2002. A comparison of circle hook and "J" hook performance in recreational catch-and-release fisheries for billfish. American Fisheries Society Symposium,30:66-79.

Prince, E.D., Snodgrass, D., Orbesen, E.S., Hoolihan, J.P. and Serafy, J.E. 2007. Circle hooks, "J" hooks and drop-back time: a hook performance study of the south Florida recreational live-bait fishery for sailfish, Istiophorusplatypterus. Fisheries Management Ecology,14: 173-182.doi:10.1111/j.13652400.2007.00539.x

Promjinda, S., Siriraksophon, S., Darumas, N. and Chaidee, P. 2008.Efficiency of the circle hook in comparison with J-hook in longline fisheries.In: Department of Fisheries (ed.) The Ecosystem-Based Fishery Management in the Bay of Bengal. Department of Fisheries, Bangkok. p.167-181.

Song, L., Li, J., Xu, W., Li, D. andChen, W. 2012.A comparison of two CPUE calculation methods for longline fishing.14. Working Party on Tropical Tunas, Mauritius, (24-29 October 2012). IOTC-2012WPTTRev_2. 14-42.pp. 1-22.

SÜR-KOOP., 2008. Turkish Fishery Regulation Bulletin (2/1) for Marine and Inland Commercial Fisheries in Fishing Season 2008-2012, SÜR-KOOP, T.C. TKBKKGM, R.G. Say1: 26974, No: 2008/48, Ankara [in Turkish].

Suzuki, Z., Warashina, Y.,Kishida, M., 1977.The comparison of catches by regular and deep longline gears in the Western and Central Equatorial Pacific. Far Seas Fisheries Research Laboratory, Shimizu Lab, 15: 51-89.

Tibbo, S.N., Day L.R., and Doucet. W.F. 1961. The swordfish (Xiphiasgladius) its life history and economic importance in the Northwest Atlantic.Bulletin of Fisheries Research Board of Canada.130: 47.

Tserpes, G. and Tsimenides, N. 1995. Determination of age and growth of swordfish, Xiphiasgladius L., 1758, in the eastern Mediterranean using anal-fin spines.Fishery Bulletin, 93: 594-602.

Tsimenides, N. and Tserpes, G. 1989. Age determination and growth of swordfish Xiphiasgladius L., 1758 in the Aegean Sea. Fisheries Research, 8: 159-168.doi: 10.1016/0165-7836(89)90029-5.

Watson, J.,Epperly, S., Foster, D. and Shah, A. 2005. Fishing methods to reduce sea turtle mortality associated with pelagic longlines. Canadian Journal of Fisheriesand Aquatic Sciences, 62:965981.doi:10.1139/F05-004

Yokota, K., Kiyota, M. and Minami,H. 2006. Shark catch in a pelagic longline fishery: Comparison of circle and tuna hooks. Fisheries Research, 81:337341.doi:10.1016/j.fishres.2006.08.006.

Zar, J.H. 1996.Biostatistical Analysis, 3rd ed. Prentice-Hall, International, Inc. New Jersey, USA, 662 pp. 